\title{
PEMANFAATAN BUKU TEKS IPS UNTUK MENGEMBANGKAN KETERAMPILAN MENYIMAK SISWA (Penelitian Tindakan Kelas Di Kelas VII-F Sekolah Menengah Pertama Negeri 13 Bandung)
}

\author{
Oleh: \\ Lina Hasanah dan Wawan Darmawan ${ }^{1}$
}

\begin{abstract}
This article is the result of a Classroom Action Research is motivated by the observation in the previous class to use textbooks IPS is not optimal, especially if associated with literacy school culture that is still far from expectations. The problem studied much more emphasis on "How to make use of textbooks IPS that exist in order to develop listening skills of students?" The method used in this research is the Classroom Action Research, which consisted of 3 cycles with 4 times the action which includes planning, action, observation and reflection. Data collection tool used is the observational record, a list of active students, interviews and questionnaires. Based on the research results can be explained that to facilitate students in reading textbooks, making a synopsis, draw conclusions, and make a concept map to view the connectivity between the theme / topic in textbooks as part of the utilization of textbooks IPS turned out to have been able to develop listening skills of students in learning IPS, especially students of class VII-F SMPN 13 Bandung. Other results with the use of textbooks IPS students can also communicate the content of textbooks IPS, both oral and written well.
\end{abstract}

Keywords: Textbooks, IPS Learning, Listening Skills, and PTK

\begin{abstract}
ABSTRAK
Artikel ini merupakan hasil Penelitian Tindakan Kelas yang dilatarbelakangi oleh hasil pengamatan di kelas sebelumnya terhadap penggunaan buku teks IPS yang belum optimal apalagi jika dikaitkan dengan budaya literasi sekolah yang masih jauh dari harapan. Masalah yang dikaji lebih lebih menekankan pada "Bagaimana memanfaatkan buku teks pelajaran IPS yang ada agar dapat mengembangkan keterampilan menyimak siswa?" Metode yang digunakan dalam penelitian ini adalah Penelitian Tindakan Kelas (PTK) yang terdiri dari 3 siklus dengan 4 kali tindakan yang meliputi perencanaan, tindakan, observasi dan refleksi. Alat pengumpul data yang digunakan ialah catatan observasi, daftar keaktifan siswa, wawancara dan angket. Berdasarkan hasil penelitian dapat dijelaskan bahwa dengan memfasilitasi siswa dalam membaca buku teks, membuat sinopsis, menarik simpulan, dan membuat peta konsep untuk melihat keterhubungan antar tema/topik dalam buku teks sebagai bagian dari pemanfaatan buku teks IPS ternyata telah dapat mengembangkan keterampilan menyimak siswa dalam pembelajaran IPS, khususnya siswa kelas VII-F SMPN 13 Bandung. Hasil lainnya dengan pemanfaatan buku teks IPS siswa juga dapat mengkomunikasi konten buku teks IPS, baik lisan maupun tulisan dengan baik.
\end{abstract}

Kata Kunci: Buku Teks, Pembelajaran IPS, Keterampilan Menyimak, dan PTK

\footnotetext{
${ }^{1}$ Lina Hasanah adalah guru IPS di SMPN 13 Bandung dan Wawan Darmawan adalah dosen di Departemen Pendidikan Sejarah FPIPS UPI
} 


\section{PENDAHULUAN}

Ilmu Pengetahuan Sosial (IPS) yang ada dalam mata pelajaran di sekolah merupakan mata pelajaran yang dibangun dari berbagai konsep ilmu-ilmu sosial yang terintegrasi. Hal ini sebagaimana dijelaskan oleh Somantri (dalam Sapriya, 2014: 11) bahwa pendidikan IPS pada dasarnya merupakan penyederhanaan atau adaptasi dari disiplin ilmu-ilmu sosial dan humaniora, serta kegiatan dasar manusia yang diorganisasikan dan disajikan secara ilmiah dan pedagogis atau psikologis untuk tujuan pendidikan. Objek kajian IPS jelas sebagai suatu pendekatan terhadap hal-hal yang berkenaan dengan manusia dan masyarakat serta lingkungannya yang mempelajari bagaimana manusia berhubungan satu dengan lainnya. Mengacu pada penjelasan tentang IPS tersebut, dapat disimpulkan bahwa hakikatnya IPS adalah sebuah mata pelajaran yang dibangun dari berbagai konsep ilmu-ilmu sosial dengan kajian utama dalam pembelajaran IPS adalah hubungan sosial manusia dan masyarakat dengan berbagai aspek kehidupan

Dalam kehidupan sosial kemasyarakatan yang terus berkembang, setiap manusia dituntut untuk memiliki berbagai kemampuan dan keterampilan sosial yang dapat mendukung eksistensi dirinya dalam kehidupan bermasyarakat. Kecakapan sosial yang dimaksud diungkapkan oleh Sapriya (2014: 21) bahwa tujuan mata pelajaran IPS di SMP yaitu sebagai berikut.

1. Mengenal konsep-konsep yang berkaitan dengan kehidupan masyarakat dan lingkungannya.

2. Memiliki kemampuan dasar untuk berfikir logis dan kritis, rasa ingin tahu, inkuiri. Memecahkan masalah, dan keterampilan dalam kehidupan sosial.

3. Memiliki komitmen dan kesadaran terhadap nilai-nilai sosial dan kemanusiaan.

4. Memiliki kemampuan berkomunikasi, bekerjasana da berkompetisi dalam masyarakat yang majemuk, ditingkat lokal, nasional dan global.

Berdasarkan pendapat di atas sangat jelas bahwa esensi dari pembelajaran IPS berusaha untuk mengembangkan berbagai keterampilan sosial dalam diri siswa. Keterampilan sosial dalam pembelajaran IPS memiliki berbagai dimensi pokok, salah satunya yakni dimensi keterampilan berkomunikasi. Keterampilan berkomunikasi itu sendiri pada dasarnya merupakan bagian yang tidak terpisahkan dalam interaksi sosial manusia dan masyarakat (Sapriya, 2014: 51). Lebih lanjutkan Sapriya menjelaskan bahwa:

Pengembangan keterampilan berkomunikasi merupakan aspek penting dari pendekatan pembelajaran IPS khususnya dalam inkuiri sosial. Terkait dengan 
hal tersebut, Sapriya menyatakan bahwa para siswa hendaknya dimotivasi agar menjadi pembicara dan pendengar yang baik (2014:53).

Peran penting keterampilan berkomunikasi dalam inkuiri sosial dapat menjadi sarana efektif bagi siswa untuk menyadari dan memahami berbagai fenomena sosial yang terjadi di lingkungan sekitarnya. Berdasarkan hal tersebut, keterampilan berkomunikasi menjadi salah satu aspek penting yang harus diajarkan dalam pembelajaran IPS. Keterampilan komunikasi sendiri memiliki cakupan dimensi yang luas, namun pada dasarnya keterampilan komunikasi akan selalu berkaitan dengan keterampilan berbahasa. Untuk dapat berkomunikasi dengan baik, individu harus menguasai keterampilan berbahasa yang menjadi modal dasar agar komunikasi dapat dilaksanakan dengan baik. Tarigan (2013: 2) menyatakan bahwa pada dasarnya terdapat empat keterampilan berbahasa dalam melakukan komunikasi dengan baik yakni: keterampilan menyimak (listening skills), keterampilan berbicara (speaking skills), keterampilan membaca (reading skills), dan keterampilan menulis (writing skills). Dari keempat keterampilan ini, menyimak merupakan keterampilan berbahasa yang paling pertama dikuasai oleh manusia sebelum ia menguasai keterampilan berbahasa yang lain.

Dapat dikatakan bahwa menyimak menjadi dasar penguasaan bagi ketiga keterampilan bahasa yakni keterampilan berbicara, membaca dan menulis. Dengan demikian keterampilan menyimak memiliki peranan yang sangat penting dalam proses komunikasi dan interaksi sosial manusia. Tanpa adanya keterampilan menyimak yang baik, seseorang tidak akan mampu berkomunikasi dengan baik bahkan dapat menjadi salah dalam berkomunikasi. Hal itu dikarenakan menyimak merupakan kegiatan memahami dan memperoleh makna dari pesan yang ingin disampaikan selama proses komunikasi dan interaksi itu berlangsung. Hermawan lebih jauh menyatakan bahwa menyimak merupakan sebuah keahlian yang harus banyak dipelajari (2012: 35).

Berkaitan dengan pembelajaran IPS, keterampilan menyimak sebagai salah satu aspek komunikasi dan interaksi jelas perlu dikembangkan dalam pembelajaran IPS. Berkaitan dengan hal tersebut, pembelajaran IPS semestinya mampu mengembangkan keterampilan menyimak siswa sebagai modal dasar bagi dirinya dalam melakukan interaksi sosial dimasyarakat. Menyimak sebagai keterampilan yang harus dimiliki oleh seseorang (siswa) agaknya diabaikan dan belum mendapat tempat sewajarnya (Subyakto, 1988: 136). Padahal jika dikaitkan dengan pendekatan saintifik dalam Kurikulum 2013, jelas menyimak merupakan bagian dari kegiatan mengamati yang nantinya akan 
berlanjut pada kegiatan menanya, mencoba, mengolah, menyajikan, menyimpulkan, dan mengkomunikasikan. Membaca buku teks pelajaran juga merupakan bagian dari kegiatan mengamati (Darmawan, 2014).

Buku teks IPS, yang berbentuk buku pelajaran yang beredar di sekolah-sekolah, merupakan sumber utama yang selama ini digunakan oleh guru-guru untuk mengembangkan proses pembelajaran di kelas. Penggunaan buku teks akan lebih banyak manfaatnya apabila dapat digunakan secara efektif, antara lain dengan cara melatih siswa membaca secara intensif. Hal ini dapat diperkuat oleh Supriatna (2007:177) bahwa, melalui proses membaca dan mencatat tersebut siswa telah diberdayakan (empowered) untuk mengkonstruksi pengetahuan, dan mereka telah berperan sebagai individu yang otonom dan pengembang pengetahuan. Agar membaca buku teks tersebut memberikan pengetahuan keterampilan, serta mampu memberdayakan siswa dalam memperoleh dan mengolah informasi, serta memproduksi informasi melalui isi buku teks yang dibacanya, maka guru IPS perlu mengembangkan berbagai keterampilan dalam membaca teks IPS. Keterampilan membaca ini harus dapat dikembangkan dalam proses pembelajaran di kelas.

Berkaitan dengan masalah membaca buku teks yang ada kaitanya dengan keterampilan menyimak dan keterampilan sosial siswa, tampaknya perlu dibenahi atau diperbaiki. Berdasarkan hasil observasi di lapangan dimana ketika saya sebagai guru (peneliti) mengamati permasalahan keterampilan menyimak siswa dalam pembelajaran IPS ternyata masih rendah, baik ketika guru menjelaskan dengan metode ceramah ataupun dengan metode lainnya. Rendahnya keterampilan menyimak siswa kelas VII-F terlihat dari perilaku siswa yang sama sekali tidak menunjukkan respon positif dan antusias mempelajari materi atau menanya tentang materi. Berargumentasi sebagai bagian dari keterampilan menyimak tidak juga dilakukan oleh siswa. Kurangnya partisipasi siswa dalam menanya dan menjawab setiap pertanyaan baik yang disampaiakn oleh guru maupun temannya, bisa saja dikarenakan siswa tidak menyimak dengan baik materi yang disampaikan. Begitu juga ketika diberi tugas dengan kegiatan membaca buku teks IPS, kondisi kelas tidak kondusif karena kebanyakkan siswa tidak membaca, mengganggu siswa yang sedang membaca. Ketika guru memberikan pertanyaan, siswa hanya menjawab singkat tampak mampu menjelaskan keterhubungan antar tema atau konten sebagaimana yang dijelaskan dalam teks buku IPS. 
Melihat fenomena pembelajaran IPS seperti ini, peneliti ingin memperbaiki lemahnya keterampilan menyimak siswa dengan memanfaatkan buku teks IPS. Dalam pemanfaatan buku teks IPS diperlukan pembelajaran yang bermakna bagi siswa. Untuk itu diperlukan upaya untuk mengorganisasi isi pembelajaran sedekat mungkin dengan cara atau strategi pemprosesan informasi yang dilakukan siswa seperti dijelaskan oleh (Uno, 2007:148) bahwa buku teks pada dasarnya menekankan pentingnya pengorganisasian isi buku teks. Strategi pengorganisasian dibedakan menjadi 2 jenis, yaitu strategi mikro. Strategi mikro mengacu pada metode untuk pengorganisasian isi pengajaran yang berkisar pada satu konsep, prosedur atau prinsip. Strategi makro berurusan dengan bagaimana memilih, menata urutan dan rangkuman isi pengajaran (apakah itu konsep, prosedur, atau prinsip) yang saling berkaitan. Pengorganisasian buku teks antara lain: (1) isi pesannya harus dianalisis dan diklasifikasi ke dalam kategori-kategori tertentu, (2) setiap kategori harus dipenggal menjadi beberapa penggalan teks, (3) perlu ada penyajian format visualisasi untuk memberikan kemenarikan isi .

Untuk itu, permasalahan yang dikaji melalui Penelitian Tindakan Kelas ini adalah (1) Bagaimana guru merencanakan pemanfaatkan buku teks dalam pembalajaran IPS di kelas VII-F SMPN 13 Bandung? (2) Bagaimana melaksanakan pemanfaatan buku teks IPS untuk mengembangkan keterampilan menyimak siswa melalui di kelas VII-F SMPN 13 Bandung? Apakah terdapat kendala dalam memanfaatkan buku teks IPS untuk meningkatkan keterampilam menyimak siswa kelas VII-F SMPN 13 Bandung?

Dalam mengkaji permasalah di atas, peneliti menggunakan metode penelitian deskriptif dengan cara mengembangkannya melalui Penelitian Tindakan Kelas (Classroom Action Research). Metode penelitian tindakan kelas digunakan sebagai kegiatan yang dilakukan oleh guru dengan tujuan memperbaiki proses pembelajaran . Hal ini sebagaimana dijelaskan oleh Ebbut dalam Kusnandar (2008: 43) bahwa "penelitian tindakan kelas merupakan kajian sistematik dari upaya perbaikan pelaksanaan praktik pendidikan oelh sekelompok guru dengan melakukan tindakantindakan dalam pembelajaran, berdasarkan refleksi mereka mengenai hasil dari tindakantindakan tersebut." Adapun desain penelitian dengan menggunakan model yang dikembangkan oleh Kemmis \& Mc. Taggart dengan komponen planning, acting, observing, dan reflecting. Alat pengumpul data yang digunakan adalah catatan lapangan, 
pedoman wawancara, dan angket. Teknik pengumpulan datanya observasi, wawancara, dan studi dokumentasi.

\section{HASIL PENELITIAN DAN PEMBAHASAN}

\section{A. Perencanaan Pemanfaatan Buku Teks IPS Dalam Pembelajaran IPS}

Pada tahap perencanaan peneliti melakukan diskusi dengan teman sejawat dan expert/dosen dari Universitas Pendidikan Indonesia (UPI) mengenai rancangan/skenario pembelajaran dalam bentuk rencana pelaksanaan pembelajaran (RPP), media dan alat penilaian pembelajaran. Media yang banyak dipakai adalah buku teks IPS dan power point yang telah disiapkan. Alat penilaian yang digunakan berupa lembar observasi dan angket untuk menilai kemampuan siswa dalam menyimak konten/materi yang ada dalam buku teks. Selain menyiapkan perencanaan di atas, peneliti juga menyiapkan lembar observasi, lembar wawancara, dan catatan lapangan. Penyiapan mitra sebagai observer juga peneliti siapkan dalam kegiatan perencanaan sepanjang pelaksanaan PTK dengan difokuskan pada:

1) Pemanfaatan buku teks IPS

2) Kemampuan menyimak siswa dalam menggunakan buku teks IPS.

3) Keaktifan siswa dalam mengikuti kegiatan belajar mengajar di kelas yang terlihat dari kemampuannya dalam bertanya, mengemukakan pendapat, menjawab pertanyaan, menghargai pendapat siswa lain dan keaktifan dalam menggunakan buku teks.

4) Penugasan siswa dengan membaca, membuat kesimpulan dan yang terakhir membuat buku teks sesuai dengan kemampuannya masing-masing, agar terlihat bahwa siswa itu memiliki keterampilan menyimak dengan baik

5) Aktivitas guru dalam memfasilitasi siswa membaca buku teks.

Fokus pemanfaatan buku teks IPS di atas menjadi bagian penting dalam setiap perencanaan dan pelaksanaan PBM. Observer akan mengamati itu dan memberikan masukan pada saat refleksi dan hasilnya diperbaiki dalam perencanaan selanjutnya, baik perencanaan Siklus 2 maupun Siklus 3. 


\section{B. Pelaksanaan Pemanfaatan Buku Teks untuk Mengembangkan Keterampilan Menyimak Siswa Dalam Pembelajaran IPS}

Pada tahap pelaksanaan, peneliti melakukan tiga kali siklus. Setiap siklusnya terbagi ke dalam beberapa pertemuan, yang disesuaikan dengan metode dan materi yang dikaji oleh guru dalam pembelajaran di kelas. Untuk penelitian ini, pada siklus pertama terbagi ke dalam 1 pertemuan, siklus ke-2 terbagi ke dalam 1 pertemuan dan siklus ke-3 sebanyak 2 pertemuan. Dengan demikian pelaksanaan tindakan yang dilaksanakan di SMPN 13 Bandung ini berjumlah 4 pertemuan.

Pada siklus pertama, pelaksanaan proses belajar mengajar dengan memanfaatkan buku teks IPS di kelas VII-F adalah dengan menyuruh siswa untuk membaca isi buku teks dengan tema 3 "Potensi dan Pemanfaatan Sumber Daya Alam (SDA)", Subtema "Pengertian dan pengelompokan SDA, Potensi dan Sebaran SDA Indonesia". Dalam melaksanakan proses belajar mengajar pada siklus pertama ini metode yang dipakai adalah metode penugasan dengan membaca buku teks. Di sini siswa ditugaskan untuk membaca tema dan subtema selama kurang lebih 10 menit. Selanjutnya siswa disuruh mengisi lembaran tugas yang telah disediakan. Dalam pengerjaan tugas ini siswa dapat bekerja dalam kelompoknya. Setelah itu siswa mengumpulkan tugasnya dan guru memeriksa pekerjaannya. Pada siklus pertama ini guru tidak memberikan penjelasan atas teks untuk melihat apakah metode penugasan membaca buku teks dan diskusi kelompok dapat mengembangkan kemampuan menyimak siswa.

Pada Siklus yang kedua yang dilaksanakan dengan dua kali pertemuan dengan membahas "Kegiatan Ekonomi dan Pemanfaat Potensi SDA". Pelaksanaan siklus kedua ini selain menggunakan metode penugasan membaca buku teks, guru memberikan fasilitas dalam diskusi kelas agar setiap siswa dapat berdialog dengan materi yang telah dibacanya tanpa menggunakan lembar kerja siswa. Pada kegiatan ini guru memberikan fasilitas dan memoderatori kegiatan diskusi kelas. Siswa tampil ke kelas untuk menyampaikan isi bacaan dan masalah yang didapat yang berhubungan dengan pokok materi/tema. Guru juga menuntun siswa untuk diajak berdialog, mengajukan pertanyaan terbuka yang melibatkan proses berpikir siswa sebagai bagian dari keterampilan menyimak.

Pada Siklus ketiga kegiatan dilaksanakan seperti pada Siklus kedua, tetapi karena dirasa masih kurang dalam keterampilan menyimak siswa atas buku teks yang dibacanya, peneliti menambahkan kegiatan berupa pemberian tugas yang lebih sedikit 
komprehensif. Tugas ini ditujukan untuk melihat keterhubungan antar tema, keterhubungan dengan permasalahan yang terjadi pada kehidupan sekarang, dan mengkontruksi gejala yang dapat diprediksi pada kehidupan ke depan. Guru pada tahap ketiga ini memberikan arahan dan membimbing siswa agar pemahaman terhadap teks dan realita di lapangan dapat dipahami dengan baik.

Berdasarkan hasil pengamatan, peneliti bersama kolaborator melakukan analisis terhadap seluruh proses belajar mengajar di kelas. Hasil pengamatan atau observasi menjadi bahan merefleksi untuk perbaikan pada siklus berikutnya dan itu tampak dari perbaikan pelaksanaan pada setiap siklus (sebagaimana dijelaskan di atas). Masukan dan perbaikan hasil observasi diantaranya : (1) sebagian besar siswa belum membaca buku teks IPS dengan baik, (2) sebagian siswa belum mengerti dengan isi teks, (3) siswa belum terlihat aktif secara keseluruhan dalam kegiatan diskusi, (4) siswa belum mampu menghubungan antar tema dan permasalahan yang terjadi dalam kehidupan sosialnya, (5) guru kurang memberi arahan bagaimana cara membaca teks yang baik, (6) guru kurang membimbing dan memotivasi siswa dalam pemanfaatan buku teks, (7) guru perlu secara mengawasi dan memberikan bantuan ketika penugasan membaca teks, dan (8) lembar kegiatan yang harus dikerjakan siswa yang berhubungan dengan teks harus jelas dan komphensif sehingga keterampilan menyimak siswa dapat terukur. Permasalahan dan masukan dari observasi itu selanjutnya peneliti dengan mitra memperbaiki dalam perencanaan kembali untuk dilaksanakan pada siklus kedua dan ketiga. dibantu oleaktif andangan guru lebih terfokus pada satu arah, hanya siswa yang aktif sehingga siswa yang lain kurang termotivasi.

Adapun hasil yang diperoleh selama melakukan tindakan dalam memanfaatkan buku teks untuk mengembangkan keterampilan menyimak siswa kelas VII-F di SMPN 13 Bandung dengan indikator:

1. Siswa menunjukan respon positif dan sikap penuh perhatian terhadap pemaparan guru

2. Siswa menunjukan sikap penuh perhatian terhadap pemaparan pembicara mengenai wacana yang dibacakan

3. Siswa mampu selektif memilih dan menuliskan bagian-bagian penting bersifat inti (ide pokok) dari bahan wacana yang perlu dicatat dan diingat

4. Siswa mampu menginterpretasikan bagian-bagian penting bersifat inti dari bahan wacana yang telah ia catat sebelumnya 
5. Siswa mampu menjelaskan hasil kegiatan menyimak wacana yang telah dilakukannya secara berkelompok dalam kegiatan presentasi hasil laporan kelompok di depan kelas

dapat dijelaskan sebagai berikut.

1. Pada siklus pertama keterampilan menyimak siswa kelas VII-F masih rendah. Peningkatan secara bertahap terlihat dalam indikator kedua, keempat dan kelima. Peningkatan pada indikator kedua didorong oleh siswa yang mulai mampu memahami apa yang harus dilakukan dalam kegiatan menyimak wacana. Kemajuan dalam indikator kedua terlihat dari siswa yang mulai mampu menginterpretasi catatan hasil menyimaknya untuk mengisi pertanyaan dalam LKS meskipun belum optimal memanfaatkan hasil menyimaknya. Selanjutnya salah satu peningkatan terkait dengan indikator kelima yakni siswa mampu mempresentasikan laporan hasil diskusinya meskipun masih malu-malu. Adapun pencapaian indikator kedua pertama dan ketiga yang lebih rendah dibanding tiga indikator lainnya salah satu faktor penyebabnya yakni media yang ditampilkan belum mampu menarik minat untuk menyimak dan siswa yang belum memahami betul bagaimana selektif memilah dan memilih informasi penting dari wacana yang disimak.

2. Pada siklus kedua dan ketiga dapat dilihat adanya peningkatan yang signifikan dalam setiap indikator keterampilan menyimak siswa. Peningkatan dalam indikator pertama, kedua, ketiga dan keempat mampu dicapai atas dukungan berbagai faktor, salah satu faktor utama yakni pemahaman siswa mengenai kegiatan apa saja yang harus dilakukan selama wacana dibacakan semakin baik. Siswa yang sudah pernah melakukan kegiatan pembelajaran dengan menyimak wacana pada siklus pertama menunjukan sikap tidak asing dan tidak kebingungan lagi saat melakukan kegiatan menyimak di siklus kedua dan ketiga. Di sisi lain inisiatif siswa untuk mempersiapkan diri dan alat tulis sebelum menyimak wacana berlangsung menjadi salah satu peningkatan yang baik dalam keterampilan menyimak siswa di siklus kedua dan ketiga. Adapun indikator yang masih rendah yakni mengenai kemampuan siswa dalam menjelaskan hasil diskusi kelompok dalam kegiatan presentasi, rendahnya indikator tersebut dapat dilihat dari kurang kondusifnya kegiatan presentasi akibat siswa yang lain tidak memperhatikan temannya yang presentasi (kelas sedikit ribut dan ada 
keengganan tidak menyimak paparan penyaji). Kondisi tersebut menunjukan bahwa minat siswa dalam mengikuti kegiatan presentasi masih rendah.

Berikut tabel persentase keterampilan menyimak siswa kelas VII-F dalam tiga siklus yakni:

\section{Tabel 1.1. Persentase Penilaian Keterampilan Menyimak Siswa}

\begin{tabular}{|c|c|c|c|}
\hline $\begin{array}{c}\text { Keterampilan Menyimak } \\
\text { Siswa }\end{array}$ & Siklus 1 & Siklus 2 & Siklus 3 \\
\hline Jumlah Akumulasi Skor & 8 & 14 & 17 \\
\hline Jumlah Skor Maksimal & 20 & 20 & 20 \\
\hline Persentase & $40 \%$ & $70 \%$ & $85 \%$ \\
\hline
\end{tabular}

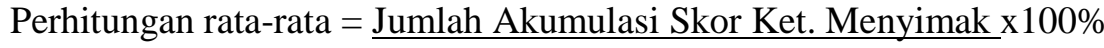
Jumlah Skor Maksimal

Konversi Rata-Rata (Persentase)

\begin{tabular}{|c|c|}
\hline Nilai & Skor Persentase \\
\hline Kurang & $0 \%-25 \%$ \\
\hline Cukup & $26 \%-50 \%$ \\
\hline Baik & $51 \%-75 \%$ \\
\hline Sangat Baik & $76 \%-100 \%$ \\
\hline
\end{tabular}

Berdasarkan tabel di atas dapat diketahui peningkatan keterampilan menyimak siswa kelas VII-F dalam setiap siklus. Siklus pertama memperoleh skor terendah dibanding tiga siklus lain yakni sebesar $40 \%$. Siklus kedua memperoleh skor sebesar 70\%, hal ini menunjukan bahwa keterampilan menyimak siswa mengalami peningkatan sebesar $30 \%$. Skor siklus ketiga sebesar $85 \%$ dan mengalami peningkatan sebesar $10 \%$ dari siklus kedua. Peningkatan yang diperoleh dalam tiap siklus tentu dipengaruhi oleh berbagai faktor, pemahaman siswa mengenai cara-cara menyimak yang terus meningkat ditiap siklus kiranya menjadi salah satu faktor yang mempengaruhi peningkatan tersebut. Berikut peneliti sajikan grafik peningkatan keterampilan menyimak siswa kelas VII-F: 


\section{Grafik Penilaian Keterampilan Menyimak Siswa}

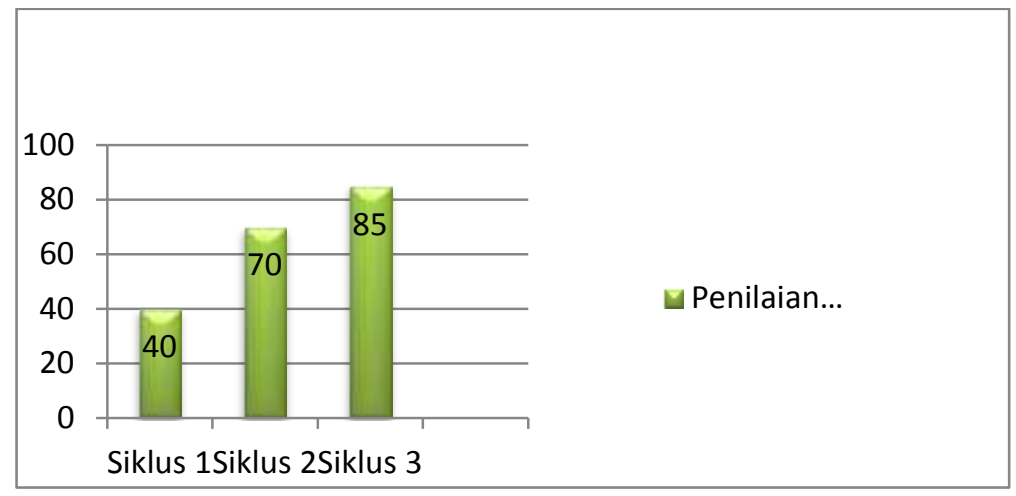

Berdasarkan grafik di atas dapat dilihat dengan jelas penilaian keterampilan menyimak siswa kelas VII-F masing-masing siklus. Perolehan skor terendah diperoleh pada siklus pertama dibanding siklus lain, adapun skor tertinggi diperoleh siklus ketiga. Peningkatan yang terjadi dalam setiap tindakan terjadi secara bertahap sesuai dengan pencapaian indikator keterampilan menyimak siswa pada tiap siklusnya.

\section{SIMPULAN}

Berdasarkan hasil penelitian tindakan kelas yang telah dilakukan dapat disimpulkan bahwa siswa yang sebelumnya memiliki keterampilan menyimak buku teks rendah maka setalah dilakukan PTK keterampilan menyimak siswa terhadap buku teks IPS menunjukkan peningkatan. Siswa kelas VII-F SMPN 13 Bandung ketika dihadapkan dengan buku teks IPS telah mampu selektif memilih dan menuliskan bagian-bagian penting bersifat inti (ide pokok) dari bahan wacana yang perlu dicatat dan diingat. Siswa juga telah mampu menginterpretasikan bagian-bagian penting bersifat inti dari bahan wacana yang telah ia catat sebelumnya. Hasil lainnya dengan pemanfaatan buku teks IPS siswa juga dapat mengkomunikasi konten buku teks IPS, baik lisan/presentasi maupun tulisan (membuat sinopsis) dengan baik.

\section{DAFTAR PUSATAKA}

Darmawan, Wawan. 2014. "Implementasi Kurikulum 2013 (Kajian terhadap Problematika guru-guru SMP dan SMA dalam Implementasi kurikulum 2013 di Sekolah". Proceedings International Seminar on Current Issues of Curriculum development in Indonesia and Taiwan. Bandung: SPs UPI 
Hermawan, H. (2012). Menyimak Keterampilan Berkomunikasi yang Terabaikan. Yogyakarta: Graha Ilmu.

Kunandar. (2008). Langkah Mudah Penelitian Tindakan Kelas. Jakarta: Rajawali Pers.

Sapriya. (2014). Pendidikan IPS Konsep dan Pembelajaran. Bandung: PT Remaja Rosdakarya.

Subyakto, S.U. (1988). Metodologi PengajaranBbahasa. Jakarta: Departemen Pendidikan dan Kebudayaan.

Supriatna, Nana. 2007. Konstruksi Pembelajaran Sejarah Kritis. Bandung: Historia Utama Press

Tarigan, H.G. (2013). Menyimak sebagai Keterampilan Berbahasa. Bandung: Angkasa.

Uno, Hamzah. 2007. Model Pembelajaran. Jakarta : Bumi Aksara. 